\title{
Et land i krig (I)
}

\section{Peter Viggo Jakobsen}

\section{Bogen er et partsindlæg, der vil bevise, at Dan- mark har været på vildspor de sidste 10 år}

Lars Halskov og Jacob Svendsen: Et land i krig. Hvordan Danmark blev krigsførende - og politikere og generaler famlede i blinde. København, Politikens Forlag, 2012, 703 sider.

Et land $i$ krig skabte bølger allerede inden den blev udgivet ved at danne grundlag for en forsidehistorie i $\mathrm{Po}^{-}$ litiken om, at fem danske soldater var døde forgæves i Afghanistan, fordi Armadillo-basen først blev lukket længe efter, at den havde mistet sin militære betydning (Maltesen 2012). Historien udstiller på samme tid bogens styrke og svaghed. Beskrivelsen af processen omkring Armadillo-basens lukning bringer nye oplysninger frem, som ikke tidligere har været kendt i den brede offentlighed. Desværre er beskrivelsen ensidig og vinklet, så den understøtter forfatternes tese om, at basen udelukkende blev holdt i live af (utilstedelige) politiske og følelsesmæssige grunde. Fakta, som forfatterne kender, men som ikke passer med denne tese ignoreres. Det gælder eksempelvis det forhold, at den britiske brigade- ledelse i Helmand i både $2009 \mathrm{og}$ 2010 var imod at lukke basen (Jakobsen og Thruelsen 2011: 93, 97).

Der er naturligvis intet forkert ved at spidsvinkle et argument for at skabe opmærksomhed og debat om et vigtigt emne, hvilket er målet med denne bog. Det bliver imidlertid et problem, når forfatterne samtidig skriver, at de er ude i et helt andet ærinde, nemlig at afdække "de afgørende begivenheder hos politikerne, militærledelsen og soldaterne ved fronten, så læserne selv kan tage stilling til Danmarks deltagelse i krigene". De skriver endvidere, at de har forholdt sig kritisk til deres kilder, og at deres oplysninger er "kontrolleret, krydstjekket og sammenholdt med andre kilders beskrivelse af samme begivenhed" (Halskov og Svendsen 2012: 8). Hvis formålet er at afdække og fremlægge data, så læserne selv kan tage stilling til krigene på et kvalificeret grundlag, som Lars Halskov har udtrykt det i et blogindlæg, fordrer det, at alle kendte relevante data lægges åbent og redeligt frem, og at man forholder sig 
kritisk til alle kilder - også dem, som siger det, man gerne vil høre.

Det er ikke den fremgangsmåde, bogen anvender. I stedet lægger den fra land med det synspunkt, at det er et mysterium og en katastrofe af rang, at Danmark er gået fra at "være optaget af humanitære opgaver og FN-missioner til at være i front $i$ offensive krige", og at "et bredt spektrum af politikere fra begge fløje er begyndt at betragte militæret som et lige så almindeligt værktøj i den politiske værktøjskasse som ulandshjælp og diplomati” (Ibid: 7).

Sat lidt på spidsen former bogen sig herefter som et forsøg på at underbygge den tese, at to 'skurke' forsvarschef Jesper Helsø og statsminister Anders Fogh Rasmussen - bærer hovedansvaret for katastrofekursen. Førstnæunte fordi han i sin iver på at sikre forsvarets eksistensberettigelse af al magt konsekvent søgte at mase forsvaret frem i forreste frontlinje uden hensyntagen til omkostningerne (Ibid: 666). Sidstnævnte fordi han på grund af sine "primitive og firkantede forestillinger om international politik" (Mogens Lykketoft karakteristik som præsenteres uden kommentarer) og sin overbevisning om, at "det altid er i Danmarks interesse at give USA opbakning", støtter de amerikanske krige i Afghanistan og Irak så meget som overhovedet muligt (Ibid: 92, 192, 666). Helten i bogens fremstilling er Mogens Lykketoft $(\mathrm{S})$, som råber vagt i gevær gentagne gange og for- gæves kæmper imod den stigende anvendelse af kampsoldater og specialstyrker (Ibid: 50, 56-57, 80, 201, 212, 431, 433).

Mens de synspunkter og tolkninger, som forfatterne er uenige i, udsættes for den annoncerede kildekritik, sker det ikke med de synspunkter, som flugter med deres egen tese. Et gennemgående tema i bogen er eksempelvis bestræbelsen på at forklare den høje politiske opbakning til krigen i Afghanistan med irrationelle motiver.

Bogen beskriver, hvordan Helle Thorning Smith og Pia Kjærsgaard bliver 'følelsesmæssigt' påvirket under et besøg i Helmand i november 2006, og det udlægges som forklaringen på, at de herefter bakker op om missionen. Tolkningen hviler dog på et spinkelt kildegrundlag, idet forfatterne ikke talt med de to hovedpersoner og kun har det fra anden hånd. Hertil kommer, at de lader Holger K. Nielsen (SF), en politisk modstander, som end ikke var med på turen, fælde dom over, hvad turen kom til at betyde for Socialdemokraterne og Dansk Folkepartis videre håndtering af Afghanistan (Ibid: 435-436). At Socialdemokraternes og Dansk Folkepartis Afghanistan politik skal forklares med irrationelle, følelsesmæssige motiver forekommer lidet sandsynligt.

I hvert fald er det let at finde en alternativ rationel politisk forklaring. Dansk Folkeparti udgjorde som bekendt det parlamentariske 


\section{LITTERATUR}

grundlag for Fogh/Løkke Rasmussen-regeringerne, og så delte Dansk Folkeparti desuden regeringens synspunkt, at islamisk-inspireret terrorisme skulle bekæmpes med militær magt, og at Danmark skulle give USA maksimal støtte - det dokumenteres fint i bogen (Ibid: 87-88). Socialdemokraterne havde, da det begyndte at stramme til i Afghanistan, travlt med at signalere regeringsduelighed og ønskede ikke gøre sig sårbar over for den fodnotekritik, som de altid får i hovedet fra blå blok, hvis de begynder at sætte spørgsmålstegn ved NATOs og USA's politik. At SF kraftigt nedtonede sin kritik af Afghanistan og indgik i forsvarsforliget af 2009 skyldes nok også mere, at $\mathrm{SF}$ gerne ville i regering, og mindre at Holger $\mathrm{K}$. Nielsen også blev følelsesmæssigt berørt under et Helmand besøg i 2009 (Ibid: 524).

\section{Tvivlsomt hovedargument}

Man kan også med udgangspunkt i bogens egne oplysninger sætte spørgsmålstegn ved dens hovedargument om, at de ansvarlige politikere og generaler famlede i blinde. Ja, juleflyvningen til Afghanistan i 2001 viste, at Flyvevåbnet bevægede sig ud i ukendt terræn og måtte improvisere. Ja, der var løbende problemer med manglende uddannelse og materiel. Og ja, efterretningerne var meget mangelfulde, da danskerne blev indsat i Helmand provinsen.
Men bogens gennemgang af perioden viser også, at politikerne holdt fast, når konsekvenserne af deres handlinger blev synlige. Efter de hårde kampe i Musa Qala i august 2006, var der ingen, som var i tvivl $\mathrm{om}$, at missionen ville blive farlig og koste menneskeliv. Alligevel holdt et bredt flertal i Folketinget fast i operationen. Det blev det ved med, også selvom tabene voksede. De politikere, der havde sagt A, sagde også B og C på tidspunkter, hvor de var fuldt bevidste om prisen.

På samme måde viste Forsvaret også evne til at lære af sine fejl og tilpasse doktriner og operationsmåder. Det flyvevåben, der var klar til at føre an i bombningerne over Libyen i marts 2011, kun 57 timer efter at FN havde givet grønt lys for brug af militærmagt (Jakobsen og Møller 2012: 114), var et helt andet end det, der satte kursen mod Afghanistan midt $i$ en julefrokost $i$ 2001. Politikere og generaler, der holder fast og tilpasser politikken til udviklingen på jorden i missionsområderne $o g$ i storpolitikken, famler for mig at se ikke i blinde. De gør op med sig selv, at den valgte kurs er rigtig og prisen værd.

Det er forfatterne dybt uenige i, men det betyder jo ikke, at disse politikere og generaler famler i blinde.

Bogen er med andre ord et partsindlæg. Den forsøger at føre bevis for, at Danmark har været på vildspor de sidste 10 år, og slutter med en bøn om, at danske politikere nu 
vil besinde sig og vende tilbage til de gode gamle dage, hvor Danmark koncentrerede sig om konfliktforebyggelse og fredelig konfliktløsning og overlod det til andre at bruge militær magt offensivt (Halskov og Svendsen 2012: 672-73). Forfatterne ligger dermed på linje med Paul Villaume som længe og vedholdende har fremført samme synspunkt i den danske debat (fx Villaume 2012).

\section{Afdækning af omkostningerne}

Gennem sin systematiske afdækning af de omkostninger, som den danske krigsdeltagelse har haft, leverer bogen et vigtigt bidrag til diskussionen om, hvorvidt det militære instrument også fremover skal have en fremtrædende rolle i Danmarks aktivistiske udenrigspolitik, når de danske kamptropper har forladt Afghanistan ved udgangen af 2014.

Det ville imidlertid have tjent forfatterne til ære, om de havde tonet rent flag fra starten fremfor at påstå, at de selv vil lade læserne tage stilling. Forfatterne har helt ret, når de i slutningen af bogen skriver at "[d]er er brug for en nøgtern analyse af de ti års krig i især Afghanistan og Irak" (Halskov og Svendsen 2012: 666). Den analyse leverer bogen ikke, og det er en skam. Den kunne, qua det store materiale den gennemgår, have placeret sig som det hovedværk, alle fremtidige analyser af Danmarks engagement i Irak og Afghanistan måtte forholde sig til.
Dermed ikke sagt, at bogen ikke er værd at læse. Det er den. Den kaster nyt lys over Danmarks krigsdeltagelse. Det gælder oplysningerne om, at Anders Fogh Rasmussen allerede i 2001 var klar til at sende danske specialstyrker i krig i Afghanistan med et snævert flertal bestående af regeringens og Dansk Folkepartis stemmer (Ibid: 86), beskrivelsen af den dramatiske juleflyvning, som bringer danske jægersoldater til Afghanistan i 2001 (Ibid: 101-107), og forsvarets forslag om at Danmark kunne stille en bataljon til rådighed for briterne i forbindelse med invasionen af Irak (Ibid: 168-169).

Der er dog langt mellem snapsene. Hvis man har læst flere af de øvrige bøger, der er udkommet om krigene, eller har fulgt med i mediedækningen i de store dagblade, vil størstedelen af bogen fremstå som en gentagelse af kendt stof. Bogens gennemgang af Irakkrigen bygger i høj grad på et sammenkog af Kaae og Nissens Vejen til Irak og Bjerre, Larsen og Stougaards Blindt ind $i$ Basra. Analysen af Danmarks problemer med at håndtere fanger i Irak i overensstemmelse med de folkeretslige forpligtigelser læner sig meget op af Informations dækning, og der lånes også meget fra Hundevadts, $I$ morgen angriber vi igen, Ulslevs $D e$ danske tigre, og Woodwards Bush at War og Obamas Wars. Siderne 214216 minder til forveksling om Brøndum (2004). Hvis man som forsker havde lånt så meget fra en anden 


\section{LITTERATUR}

kilde uden at angive det direkte, havde man fået ørerne i maskinen. Men der gælder åbenbart andre regler for 'journalistiske' bøger.

Alt det genbrug taget i betragtning er bogen for lang. Frem for at opbygge bogen kronologisk uden nogen klart gennemskuelig logik for, hvordan de mange begivenheder er udvalgt (de er langt fra 'afgørende' alle sammen), ville bogen have stået sig bedre ved en mere fokuseret tilgang. Forfatterne kunne med fordel have gået i dybden med en række emner, som de fandt særligt vedkommende.

Emner, der berøres i bogen men som skriger på en dyberegående analyse er: 1) den store politiske og folkelige opbakning til krigene, der klart overstiger det, man ser i andre lande, 2) hvordan skiftende danske regeringer har evnet at fastholde denne opbakning, 3) Forsvarsministeriets energiske bestræbelser på at undgå at pådrage sig et juridisk ansvar for fanger i Irak og Afghanistan, og 4) hvorvidt den danske presse har været for ukritisk i sin dækning af krigene. Det kunne have bidraget til en kortere, klarere og måske mere overbevisende bog.

Hvis man gerne vil have en kort, samlet og balanceret gennemgang af Danmarks krigsdeltagelse i perioden 1990-2011 er Hans Branners I krig igen et bedre alternativ.

Peter Viggo Jakobsen, lektor, ph.d., Institut for Strategi, Forsvarsakademiet.

\section{Litteratur}

Bjerre, M, Larsen, J og Stougaard, KE (2008) Blindt ind i Basra. Gyldendal.

Branner, Hans (2011) I krig igen. Danmark og de nye krige 1990-2011. Columbus

Brøndum, C (2004) Generalens længste dag. Berlingske, 11. april. Tilgængelig på: http://www.b.dk/danmark/generalens-laengste-dag

Hundevadt, K (2008) I morgen angriber vi igen. Jyllands-Postens Forlag.

Jakobsen, PV og Møller, KJ (2012) Good News: Libya and the Danish Way of War i Hvidt, N og Mouritzen H (red) Danish Foreign Policy Yearbook 2012. Danish Institute for International Studies.

Jakobsen, PV og Thruelsen PD (2011) Clear, Hold, Train: Denmark's Military Operations in Helmand 2006-2010 i Hvidt, $\mathrm{N}$ og Mouritzen H (red) Danish Foreign Policy Yearbook 2011. Danish Institute for International Studies.

Johannesen, LU (2008) De danske tigre: Med livet som indsats i Afghanistan. Gyldendal.

Kaae, M og Nissen, J (2008) Vejen til Irak. Gads Forlag.

Maltesen, B (2012) Søren Gade og forsvarets top nægtede at lukke basen Armadillo, selv om den havde mistet sin militære betydning. Imens døde flere soldater ved basen. Politiken, 19. april.

Villaume, P (2012) Danmarks rolle er som diplomatisk stifinder. Politiken, 22. juni.

Woodward, B (2003) Bush at War (Simon \& Schuster).

Woodward, B (2010) Obama's Wars (Simon \& Schuster). 